\title{
PEMBINAAN LAPORAN KEUANGAN DENGAN MEMANFAATKAN SOFTWARE APPLICATION
}

\author{
Sunarsan Sitohang \\ Universitas Putera Batam (UPB), Batam, Indonesia \\ e-mail: sunarsan@puterabatam.ac.id \\ Very Karnadi \\ Universitas Putera Batam (UPB), Batam, Indonesia \\ e-mail: very@puterabatam.ac.id \\ Cosmas Eko Suharyanto \\ Universitas Putera Batam (UPB), Batam, Indonesia \\ e-mail: cosmas@puterabatam.ac.id
}

\begin{abstract}
The convenience that is currently obtained in doing work is the role of rapidly developing technology and the need to complete a job quickly. It is undeniable that there are still many people who are very reluctant to technology use. This reluctance can be caused by lack of will learning or inadequate facilities and the absence of motivating or construction. Guidance on the use of application software aims to make Church administrators Bethel Indonesia (GBI) Rawa Indah RT.03 RW.12 No.10 Kibing Batu Aji can understand how to use application software, namely Microsoft office excel to assist in how to use application software for good church activities in the form of making good financial reports, good invitation letters and others etc. The method of service carried out is by providing material about the use of application software in the form of tutorials that are made simply with easy-to-understand steps and direct practice and accompanied by a coaching team in addition to that will be given training to evaluate the level of understanding of the coaching participants. Therefore, application software development it will be indispensable for church administrators who are interested in studying it. The main target of this development is to create a society that can implement technology, especially application software to make it easier to work on work, especially in financial reporting by utilizing software application and understand how to use the application software. Results dedication shows that the targets set can be achieved, namely the management GBI Rawa Indah church can apply Microsoft Excel to make reports finance.
\end{abstract}

Keywords_Financial Statements, Software, Application, Microsoft Excel

\section{PENDAHULUAN}

K emudahan yang didapat saat ini dalam mengerjakan pekerjaan adalah peran dari teknologi yang berkembang pesat serta keharusan menyelesaikan suatu pekerjaan dengan cepat. Dengan adanya dorongan untuk menyelesaikan pekerjaan lebih cepat dari sebelumnya maka pengembang teknologi berlombalomba untuk mengembangkan teknologi yang mereka buat sehingga lebih baik dari sebelumnya. Teknologi saat ini sangat banyak jenisnya, yang pada intinya 
tujuannya adalah membantu dan mempermudah pekerjaan manusia. Salah satu perkembangan teknologi yang sangat pesat saat ini adalah komputer.

Komputer merupakan salah satu alat yang sangat membantu pekerjaan manusia saat ini. Salah satu program komputer yang sangat banyak dipakai saat ini untuk membantu pekerjaan manusia adalah Program aplikasi perkantoran. Salah satu program aplikasi perkantoran yang cendrung digunakan saat ini adalah Microsoft Office. Program aplikasi merupakan salah satu pengembangan dalam teknologi komputer. Sangat banyak sekali aplikasi yang dibuat baik perorangan maupun perusahaan dengan tujuan yang beragam. Pada intinya tujuan dari program aplikasi tersebut secara umum adalah mempermudah pekerjaan manusia. Kebutuhan program aplikasi di zaman yang serba canggih seperti sekarang ini tentunya akan menjadi sangat penting sama halnya seperti kebutuhan sehari-hari.

Jenis dan kapasitas program aplikasi yang diperlukan pun tentu akan beragam untuk menyelesaikan suatu masalah. Tidak sedikit orang menggunakan program aplikasi sebagai alat bantu untuk mengerjakan pekerjaannya. Pengaplikasian tersebut dapat dilakukan dengan berbagai cara diantaranya adalah dengan melalui komputer sebagai media atau alat penyampaian informasi. Dengan sistem terkomputerisasi yang bertujuan untuk meningkatkan mutu dan kualitas suatu aplikasi, diharapkan hasilnya akan memberikan solusi serta mengambil keputusan dengan tepat. (Rosa \& Shalahuddin, 2011).

Software aplikasi yang dimaksud adalah miscrosoft excel. Microsoft office adalah applikasi pengolah kata, excel adalah sebuah program aplikasi lembar kerja spreadsheet yang dibuat dan didistribusikan oleh Microsoft Corporation yang dapat dijalankan pada Microsoft Windows dan Mac OS dan powerpoint adalah sebuah program untuk presentasi (Jarot S., Shenia A., 2012).

Suatu organisasi yang berbadan hukum merupakan organisasi yang telah legal. Di negara Indonesia terdapat begitu banyak jenis organisasi legal seperti organisasi masyarakat, bidang usaha, perusahaan, instansi, departemen baik yang bersifat milik negara ataupun swasta. Gereja Bethel Indonesia Jemaat Rawa Indah merupakan suatu organisasi keagamaan yang telah legal. Situasi yang kami lihat dilapangan menunjukkan bahwa masih ada beberapa pengurus Gereja yang belum paham bagaimana pemanfaatan program aplikasi komputer serta kurang memahami bagaimana menggunakan komputer untuk dimanfaatkan dalam pembuatan laporan keuangan gereja. Pengusul melihat bahwa pembuatan laporan gereja masih manual sehingga kurang rapi dan masih rentan terjadinya kesalahan dalam pengolahan data keuangan tersebut.

\section{METODE}

Adapun solusi yang akan ditawarkan adalah tim pengabdi akan membuatkan pembinaan dalam memanfaatkan software aplikasi yaitu microsoft Office Excel untuk membuat laporan keuangan bagi pengurus gereja. Pemberian berupa tutorial yang sederhana dan detail sehingga dapat diikuti dengan benar dan tepat serta memberikan pelatihan praktek penerapannya. Selain itu pengusul akan memberikan latihan sebagai evaluasi pemahaman akan materi pelatihan yang pengusul berikan. 
Metode yang dilaksanakan oleh pengabdi adalah memberikan materi dan praktek langsung tentang bagaimana memanfaatkan software aplikasi untuk membuat laporan keuangan. Dalam pelaksanaan setiap peserta akan mendapatkan salinan materi yaitu berupa tutorial yang telah disiapkan sesuai dengan kebutuhan pengurus Gereja dan mengarahkan ke laporan keuangan yang berstandard umum maupun khusus sesuai permintaan.

Tabel 1 Waktu dan Tempat Pelaksanaan

\begin{tabular}{llll}
\hline No & $\begin{array}{l}\text { Waktu } \\
\text { Pelaksanaan }\end{array}$ & Uraian Kegiatan & Bentuk Kegiatan \\
\hline 1 & 5 Desember 2017 & $\begin{array}{l}\text { Survey Lokasi } \\
\text { Pengabdian }\end{array}$ & Diskusi masalah \\
2 & $6-18$ Desember & $\begin{array}{l}\text { Persiapan } \\
\text { Proposal }\end{array}$ & $\begin{array}{l}\text { Pembuatan } \\
\text { Diskusi solusi }\end{array}$ \\
3 & 2017 & $\begin{array}{l}\text { Penyerahan } \\
\text { Penyerahan }\end{array}$ & Proposal \\
4 & 2017 & $\begin{array}{l}\text { Pelaksanaan } \\
\text { Pengabdian }\end{array}$ & $\begin{array}{l}\text { Diskusi Training } \\
\text { (praktek) }\end{array}$ \\
5 & 4 Februari 2018 & $\begin{array}{l}\text { Pelaksanaan } \\
\text { Pengabdian }\end{array}$ & $\begin{array}{l}\text { Training Evaluasi } \\
\text { hasil Training }\end{array}$ \\
\hline
\end{tabular}

Adapun rincian pelaksanaannya adalah sebagai berikut:

Ketua pengabdi:

1. Menyampaikan kata pembukaan, pengenalan software application, manfaat dan kegunaannya khususnya miscrosoft office secara umum

2. Meyampaikan materi miscrosoft office excell: langkah-langkah menjalankan, membuat tabel sederhana, menarik dan input data ketabel yang ada.

3. Meyampaikan materi penggunaan format, tabel propertis, formula dan function dan membagikan laporan keuangan dengan aplikasi whats up maupun email.

Anggota pengabdi:

1. Pengenalan menu-menu yang ada di miscrosoft excel serta kegunaanya, seperti menu insert, page layout, formulas, data, review dan lain sebagainya.

2. Memberikan soal evaluasi pada semua materi yang telah diberikan dan melakukan pengawasan sehingga benar-benar peserta mandiri dalam mengerjakan soal yang diberikan.

3. Menangani pelaksanaan praktek, memandu cara untuk mengerjakannya.

\subsection{Tahapan Review}

Evaluasi yang pengabdi lakukan adalah dengan memantau secara langsung pelatihan yang diselenggarakan, apakah peserta dapat mengikuti pelatihan dengan baik atau penyampaian materi atau prakteknya terlalu cepat atau tidak. Kemudian nantinya akan diuji peserta pelatihan dengam menggunakan software aplikasi tersebut, pengujiannya berupa pemberian latihan yang relevan dengan materi pelatihan yang diberikan. 


\section{2 Keberlanjutan kegiatan}

Pembinaan yang akan dilakukan oleh pengabdi akan dilanjutkan dengan memonitor peserta dan membantu mengembangkan kemampuannya dalam penggunaan software aplikasi sampai dengan mahirnya untuk administrasi organisasi. Jika kedepannya peserta pengabdian mengalami kendala, tim pengabdi siap untuk membantu dan membina kembali.

\section{HASIL DAN PEMBAHASAN}

Hasil dari kegiatan pengabdian ini adalah para pengurus gereja khususnya bendahara umum dan kaum pemuda-pemudi GBI Rawa Indah RT.03 RW.12 No.10 Kibing Batu Aji paham bagaimana memanfaatkan software application dan komputer untuk membuat laporan keuangan. Adapun rincian hasil pembinaan adalah sebagai berikut:

1. Waktu survey Sebelum tim pengabdi yang merupakan dosen dan mahasiswa pada program studi Teknik Informatika Universitas Putera Batam turun untuk melaksanakan kegiatan pengabdiaan kepada masyarakat ini tim pengabdi telah terlebih dahulu melakukan survey atau observasi pendahuluan, dimana kegiatan survey ini dilaksanakan pada tanggal 10 Desember 2017. Survey yang dilakukan oleh tim pengabdi tersebut meliputi hal-hal sebagai berikut:

a. Survey tempat/lokasi pelaksanaan pengabdian kepada masyarakat yang akan diadakan oleh tim pengabdi

b. Silahturahmi dengan pengurus gereja khususnya pendeta, bendahara umum dan kaum pemuda-pemudi GBI Rawa Indah RT. 03 RW. 12 No. 10 Kibing Batu Aji. Pada kesempatan itu tim pengabdi menyampaikan maksud dan tujuan yaitu ingin melakukan kegiatan pengabdian kepada masyarakat. Setelah itu, terjadi perbincangan tentang kegiatan pengabdian yang harus dilakukan. Didalam perbincangan itu ada dua kegiatan yang diusulkan oleh pengurus gereja sesuai dengan kebutuhan gereja yaitu kegiatan pembuatan website gereja dan laporan keuangan. Oleh karena keterbatasan jumlah kegiatan hanya satu kegiatan maka terpilihlah pembuatan laporan keuangan, karena pembuatan laporan keuangan gereja merupakan hal yang lebih penting dan dibutuhkan dalam waktu dekat sehingga laporan keuangan gereja dapat memberikan informasi yang tepat, akurat dan mudah untuk membuatnya. Adapun laporan keuangan yang ada pada saat ini di gereja GBI Rawa Indah masih menggunakan semi manual dan belum memanfaatkan sepenuhnya software application yang menawarkan kemudahan dalam membuat laporan keuangan

c. Tim pengabdi dan pengurus gereja GBI Rawa Indah RT.03 RW.12 No.10 Kibing Batu Aji menyepakati penentuan jadwal kegiatan pembinaan.

d. Tim pengabdi menyerahkan surat izin pelaksanaan kegiatan pengabdian kepada masyarakat yang dikeluarkan secara resmi oleh Universitas Putera Batam dan juga menyerahkan proposal pengadaan kegiatan pembinaan yang ditujukan kepada pendeta dan pengurus GBI Rawa Indah RT.03 RW.12 No.10 Kibing Batu Aji. Adapun surat izin dan proposal ini merupakan syarat dari pelaksanaan kegiatan pengabdian kepada masyarakat. 
Susunan pelaksanaan dan pemateri yang terlibat dalam pembinaan laporan keuangan dengan memanfaatkan software application sebagai berikut:

Tabel 2 Susunan Pelaksanaan Kegiatan

\begin{tabular}{|c|c|c|c|}
\hline Hari & Kegiatan & Nama Pelaksana & Alokasi waktu \\
\hline & Pembukaan & Ketua pengabdi & 5 Menit \\
\hline & Kata Sambutan & Pengurus gereja & 5 Menit \\
\hline Hari Pertama, 4 & $\begin{array}{l}\text { Pengenalan MS Office } \\
\text { Excel }\end{array}$ & Anggota pengabdi & $1 \mathrm{Jam}$ \\
\hline \multirow[t]{3}{*}{ Februari 2018} & $\begin{array}{l}\text { Fungsi-Fungsi Excel yang } \\
\text { umum digunakan dan } \\
\text { penerapannya }\end{array}$ & Ketua pengabdi & 1 jam \\
\hline & Latihan/Soal & Tim pengabdi & 30 Menit \\
\hline & Istirahat dan Pulang & Tim Pengabdi & \\
\hline Hari Kedua, & $\begin{array}{l}\text { Pengenalan fungsi-fungsi } \\
\text { yang digunakan dalam } \\
\text { pembuatan laporan } \\
\text { keuangan }\end{array}$ & Anggota pengabdi & 1 jam \\
\hline 11 Februari & Istirahat/makan siang & Tim pengabdi & 15 Menit \\
\hline \multirow[t]{3}{*}{2018} & $\begin{array}{l}\text { Praktek pembuatan } \\
\text { laporan keuangan }\end{array}$ & Ketua pengabdi & 1 jam \\
\hline & Latihan/Soal & Tim pengabdi & 30 Menit \\
\hline & Istirahat dan pulang & Tim pengabdi & \\
\hline
\end{tabular}

Hari Kegiatan Nama Pelaksana Alokasi Waktu jam/minggu Hari Pertama, 4 Februari 2018 Pembukaan Ketua pengabdi 5 Menit Kata Sambutan Pengurus gereja 5 Menit Pengenalan MS Office Excel Anggota pengabdi 1 Jam Fungsi-Fungsi Excel yang umum digunakan dan penerapannya Ketua pengabdi 1 Jam Latihan/Soal Tim pengabdi 30 Menit Istirahat dan Pulang Tim pengabdi Hari Kedua, 11 Februari 2018 Pengenalan fungsi-fungsi yang digunakan dalam pembuatan laporan keuangan Anggota pengabdi 1 Jam Istirahat/ makan siang Tim pengabdi 15 Menit Praktek pembuatan laporan keuangan Ketua pengabdi 1 Jam Latihan/Soal Tim pengabdi 30 Menit Istirahat dan pulang Tim pengabdi

2. Tindakan Pembinaan ini mengambil tema tentang pembinaan laporan keuangan dengan memanfaatkan software application. Materi pokok yang disampaikan tim pengabdi yaitu pengenalan microsoft office excel. Microsoft office excel yang digunakan adalah versi 2016. Adapun alasan tim menggunakan versi 2016 karena memiliki fitur tambahan jika dibandingkan dengan pendahulunya, memiliki kualitas yang bagus dan kompatibel di perangkat atau komputer merk atau keluaran manapun serta dapat dimiliki dengan harga yang relative terjangkau oleh semua kalangan baik secara personal maupun instansi atau organisasi.

Microsoft office Excel yang menjadi pilihan tim pengabdi untuk diperkenalkan dan diajarkan kepada pengurus gereja GBI Rawa Indah 
RT.03 RW.12 No.10 Kibing Batu Aji ini juga bukan merupakan tanpa alasan yang mendasar. Tim pengabdi berpendapat Microsoft Excel ini merupakan program atau software application yang bersifat mendasar dan sangat sering digunakan dalam semua kegiatan adminstrasi dan dokumentasi perkantoran.

Microsoft Excel digunakan untuk pengolahan data yang berupa angka dan sangat membantu akuntan, administrasi ataupun untuk perusahaan yang membutuhkan pengolahan angka. Aplikasi ini dapat digunakan untuk hal-hal sebagai berikut:

a. Membuat dan merancang tabel, mengurutkan data

b. Menjumlah sub total dan grand total

c. Mengedit teks atau angka secara langsung di sel

d. Menjumlah secara otomatis dengan autosum

e. Membuat grafik secara cepat dan mudah dengan fungsi chard wizard

f. Menerapkan beberapa fungsi yang umum digunakan pada Excel

g. Membuat rancangan template laporan keuangan

h. Mencetak dengan proporsi bebas.

Melalui aplikasi perkantoran ini dapat dengan mudah menyusun laporan keuangan maupun laporan pengolahan aritmatika lainnya.

Penjabaran kegiatan yang diberikan dalam kegiatan pembinaan laporan keuangan dengan memanfaatkan software application ini adalah sebagai berikut:

a. Menjelaskan, memaparkan dan memperkenalkan, mempraktekkan manfaat dan penggunaan teknologi informasi dalam membantu pengurus GBI Rawa Indah RT.03 RW.12 No.10 Kibing Batu Aji. Membantu pengurus GBI Rawa Indah dalam 9 membuat, menyusun, menyelesaikan pekerjaannya dibidang administrasi dan dokumentasi yang bersifat harian, mingguan, maupun bulanan, tahunan seperti laporan keuangan.

b. Memberikan hardcopy bahan materi dan softcopy aplication microsoft office 2016 serta membantu menginstalnya bagi yang belum memiliki dilaptopnya. Bagaimana langkah-langkah instalasi yang baik dan benar, bagaimana mendeteksi jika software yang diinstal ada file yang corrupt sehingga software tidak berjalan dengan baik.

c. Menjelaskan, memaparkan dan memperkenalkan cara memanfaatkan software application khususnya excel yang ada atau yang telah diinstal didalam komputer.

d. Software application yaitu microsoft excel yang tersedia atau yang terdapat di dalam komputer merupakan perangkat lunak siap pakai yang nantinya akan digunakan untuk membantu melaksanakan pekerjaan penggunanya. Dalam sebuah komputer aplikasi ini disiapkan sesuai kebutuhannya masing-masing.

e. Menjabarkan dan menjelaskan manfaat dan kegunaan dari microsoft office excel dalam tertib administrasi terutama dalam laporan keuangan. Seperti kemudahan dalam proses aritmatika seperti penjumlahan, pengurangan, pembagian, perkalian yang dapat dilakukan secara otomatis, manajemen laporan keuangan yang mudah serta dapat dilakukan secara online. 
f. Menjelaskan dan memaparkan jenis-jenis atau versi dari Microsoft Office yang telah familiar di kalangan pengguna aplikasi komputer untuk administrasi dokumentasi seperti Microsoft Office 2003, Microsoft Office 2007, Microsoft Office 2010, Microsoft Office 2013, dan Microsoft Office 2016. Setiap versi dijelaskan apa perbedaannya secara singkat dan mudah dipahami peserta.

g. Menjelaskan bagaimana membuat dokumen, tabel dari laporan keuangan yang selalu dibuat oleh pengurus GBI Rawa Indah RT.03 RW.12 No.10 Kibing Batu Aji akan jauh lebih mudah, cepat dan simpel dengan menggunakan software aplikasi yang dikeluarkan oleh Microsoft ini yakni Microsoft excel dibandingkan dengan cara lain seperti cara-cara yang selama ini digunakan oleh pengurus GBI Rawa Indah yaitu secara manual.

h. Menjelaskan dan memaparkan bagaimana manfaat dan kegunaan Microsoft Office Excel, membantu dalam kegiatan pembuatan laporan keuangan GBI Rawa Indah RT.03 RW.12 No.10 Kibing Batu Aji.

i. Memberikan pelatihan dasar Microsoft Excel 2016 kepada pengurus GBI Rawa Indah. Pelatihan dasar Microsoft Excel 2016 ini berupa dasar-dasar materi yang 10 dibutuhkan dalam membuat laporan keuangan seperti membuat tabel dengan beberapa cara, menginsert dengan beberapa cara, menyimpan file dengan berbagai cara, melakukan penjumlahan antar cell dengan berbagai cara, dan lain sebagainya.

j. Memberikan pendampingan pemanfaatan Microsoft office 2016 yaitu Microsoft Excel 2016 kepada pengurus GBI Rawa Indah RT.03 RW.12 No.10 Kibing Batu Aji. Pendampingan yang dilakukan seperti mengimlementasikan fungsi-fungsi dalam Microsoft Excel 2016.

k. Memberikan kesempatan kepada peserta untuk bertanya serta memberikan jawaban atas pertanyaan peserta sampai peserta yang bertanya tersebut sampai mengerti atau paham.

I. Melakukan pemantauan atau monitoring terhadap kemampuan penguasaan mereka pada Microsoft Excel 2016 yang telah diajarkan dalam pelatihan dan pembinaan ini kepada pengurus GBI Rawa Indah RT.03 RW.12 No.10 Kibing Batu Aji. Pemantauan atau monitoring yang dilakukan oleh tim pengabdi yaitu salah satu dari tim pengabdi memantau peserta pada saat tim pengabdi yang lain sedang mempraktekkan materi.

m. Melakukan evaluasi dan penilaian kepada pengurus GBI Rawa Indah RT.03 RW.12 No.10 Kibing Batu Aji yang mana mereka diwaktu sebelumnya telah diberikan pengarahan, pemaparan, pelatihan, pendampingan serta pemantauan dalam peningkatan kemampuan mereka dalam penguasaan mereka terhadap software application Microsoft office 2016 seperti Microsoft Excel 2016 yang telah diajarkan dalam pelatihan dan pembinaan ini.

3. Luaran Pengabdian

Adapun target luaran dari diadakannya pengabdian dosen mengenai Pembinaan Laporan Keuangan Dengan Memanfaatkan Software Aplication adalah pengurus GBI Rawa Indah RT.03 RW.12 No.10 Kibing Batu Aji mampu memahami, mengerti dan menggunakan software application yang dikeluarkan oleh Microsoft khususnya Microsoft Excel 2016 untuk menunjang semua kegiatan pembuatan laporan keuangan di 
lingkungan kerja mereka. Sebagaimana yang kita ketahui, Microsoft Office ini merupakan software application yang paling familiar, paling fleksibel dan paling mudah dipahami serta paling mudah untuk dipelajari sehingga dapat dipergunakan untuk membantu pembuatan laporan keuangan. Microsoft office excel juga menawarkan beberapa fungsifungsi yang mudah digunakan, disamping itu ada banyak referensireferensi yang tersedia baik buku maupun artikel di internet yang dapat digunakan 11 untuk bahan pembelajaran. Dengan pengabdian dalam bentuk pembinaan yang kami lakukan ini, kami harapkan pengurus GBI Rawa Indah RT.03 RW.12 No.10 Kibing Batu Aji sedikit banyaknya bisa mengerti apa yang sudah dilakukan tim pengabdi, khususnya dalam pembuatan laporan keuangan.

Kemungkinan permasalahan yang dihadapi meskipun materi banyak di internet adalah sulitnya mengikuti langkah-langkah yang ada oleh karena keterbatasan yang dimiliki peserta. Inilah tujuan dari pengabdian ini yaitu untuk memberi motivasi bagi mereka dan bahkan meningkatkan keinginantahuan mereka dengan memaparkan kelebihankelebihan yang ditawarkan oleh software aplikasi. Salah satu yang nyata yaitu mengurangi kesalahan-kesalahan yang terjadi seperti kesalahan perhitungan laporan keuangan dalam menjumlahkan, mengurangkan, membagi oleh karena dilakukan secara manual.

Sehingga dengan adanya pembinaan laporan keuangan dengan memanfaatkan software aplikasi ini kesalahan-kesalahan dalam laporan keuangan di pengurus GBI Rawa Indah RT.03 RW.12 No.10 Kibing Batu Aji tidak akan terjadi lagi. Pengurus-pengurus pengurus GBI Rawa Indah RT.03 RW.12 No.10 Kibing Batu Aji telah terlatih dan mampu membuat template laporan keuangan mereka sesuai dengan kebutuhan mereka.

\section{Pembahasan}

Berdasarkan hasil yang telah dijabarkan dari kegiatan pengabdian masyarakat yang telah dilakukan oleh tim pengabdi yakni memberikan pembinaan kepada pengurus gereja GBI Rawa Indah RT.03 RW.12 No.10 Kibing Batu Aji yaitu memakai Software Aplikasi komputer yang dititikberatkan pada penggunaan Software Aplikasi komputer excel yang sangat membantu penggunanya dalam pembuatan laporan keuangan. Pembinaan ini di mulai dari pemberian pemaparan, penjelasan, pelatihan, serta evaluasi mengenai hal-hal sebagai berikut:

1. Apa itu software application, manfaat software application, kaitan antara teknologi informasi dengan software application.

2. Macam-macam program atau software aplikasi komputer yang digunakan untuk memudahkan pekerjaan pengguna dalam berbagai hal.

3. Microsoft office excel sebagai salah satu software aplikasi komputer yang digunakan untuk membantu pembuatan laporan keuangan.

4. Program aplikasi andalan microsoft office dalam pembuatan laporan keuangan microsoft excel secara detil dan menyeluruh, dan dilanjutkan dengan pemberian latihan-latihan hingga pengurus gereja GBI Rawa Indah RT.03 RW.12 No.10 Kibing Batu Aji mengerti mengelola laporan keuangan dengan memanfaatkan software aplication. Latihan-latihan yang diberikan yaitu latihan-latihan yang 
merujuk pada bagaimana untuk lebih memahami membuat laporan keuangan yang baik dan benar.

5. Pemantauan atau monitoring terhadap perkembangan kemampuan para pengurus gereja GBI Rawa Indah RT.03 RW.12 No.10 Kibing Batu Aji dalam penguasaan materi Microsoft Excel untuk membuat laporan keuangan.

6. Mengukur kemampuan dari peserta pembinaan tentang tingkat pemahaman mereka kepada materi yang telah disampaikan, pengukuran kemampuan dilihat dari hasil dari latihan-latihan yang telah diberikan, berapa yang dapat dikerjakan dengan benar dan berapa yang tidak dapat dikerjakan dengan benar.

\section{KESIMPULAN}

Dari kegiatan pengabdian yang dilakukan oleh tim pengabdi di gereja GBI Rawa Indah RT.03 RW.12 No.10 Kibing Batu Aji disimpulkan sebagai berikut:

1. Memberikan pembinaan laporan keuangan berbasis komputer dengan

2. menggunakan software aplikasi khususnya microsoft office excel menjadikan pengurus gereja GBI Rawa Indah RT.03 RW.12 No.10 Kibing Batu Aji lebih memahami dan mengerti fungsi microsoft office excel tersebut.

3. Pengurus gereja GBI Rawa Indah RT.03 RW.12 No.10 Kibing Batu Aji lebih terlatih dengan menggunakan Software aplikasi khususnya Microsoft office excel.

4. Pengurus gereja GBI Rawa Indah RT.03 RW.12 No.10 Kibing Batu Aji lebih mengerti dengan fitur-fitur dari Microsoft Exel.

\section{SARAN}

Adapun saran dari kegiatan pengabdian masyarakat di gereja GBI Rawa Indah RT.03 RW.12 No.10 Kibing Batu Aji sebagai berikut:

1. Disarankan untuk memberikan pembinaan lagi pada para pengurus gereja GBI Rawa Indah yang belum mengetahui cara untuk memanfaatkan dan penggunaan dari aplikasi komputer khususnya aplikasi microsoft office excel yang merupakan andalan software aplikasi perkantoran yang dikeluarkan oleh Microsoft untuk pembuatan laporan keuangan.

2. Pengurus gereja perlu menyediakan perangkat yang berhubungan dengan teknologi untuk memanfaatkan dan menggunakan aplikasi komputer agar semua pengurus gereja terlatih dan terbiasa dengan aplikasi tersebut.

3. Berdasarkan usulan dari peserta pengabdian, mereka berharap mendapatkan sertifikat.

\section{UCAPAN TERIMA KASIH}

Penulis mengucapkan Terima kasih yang sebesar-besarnya kepada Universitas Putera Batam terutama Tim LPPM UPB atas bibmbingan dan arahan 
yang telah diberikan. Selain itu, penulis juga mengucapkan terima kasih kepada mahasiswa dan tokoh-tokoh yang terlibat dalam pengabdian ini.

\section{DAFTAR PUSTAKA}

LPPM. 2016. Panduan Pengabdian kepada Masyarakat Universitas Putera Batam. LPPM UPB Batam.

Jarot S., Shenia A., S. S. (2012). Buku Pintar Microsoft Office 2007 \& 2010: Word - Excel - PowerPoint (Pertama). Jakarta selatan:

Rosa, A., \& Shalahuddin, M. (2011). Rekayasa Perangkat Lunak (Terstruktur dan Beorientasi Objek). bandung, Indonesia: Modula. Media Kita. 